\title{
エピネフリンが異常高值を示した副腎外褐色細胞腫の一例
}

\author{
1)岩手県立中央病院第二内科, 2)岩手医科大学医学部第二内科 \\ 菅 原 隆 ${ }^{1)}$, 清 水 公1), 瀬川 郁 夫2)
}

\section{A Case of Extra-adrenal Pheochromocytoma Producing Epinephrine}

\author{
Takashi SUGAWARA ${ }^{1)}$, Kou SHIMIZU1), Ikuo SEGAWA ${ }^{2)}$
}

${ }^{1)}$ The Second Department of Internal Medicine, Iwate Prefectural Central Hospital

${ }^{2)}$ The Second Department of Internal Medicine, Iwate Medical University, Iwate, Japan

We reported a case of a 72-year-old man with an extra-adrenal pheochromocytoma secreting excessive epinephrine (E). He had been treated for diabetes mellitus and essential hypertension. His diabetes was controlled poorly, but his blood pressure was controlled well. He was admitted to our hospital for weight loss evaluation. An upper gastrointestinal series and computed tomography of the abdomen revealed an ovoid mass (diameter, approximately $5 \times 6 \mathrm{~cm}$ ) overlying the abdominal aorta and the inferior vena cava between the second and the third lumbar vertebra. Aortography showed a hypervascular mass. Analysis of catecholamine (CA) and its metabolites showed elevations in plasma norepinephrine (NE, $3850 \mathrm{pg} / \mathrm{ml})$ and E $(560 \mathrm{pg} / \mathrm{ml})$ levels as well as the urinary NE (1200-1400 $\mu \mathrm{g} /$ day), E (310-350 $\mu \mathrm{g} / \mathrm{day})$ and vanillylmandelic acid (26.8 mg/ day) levels. Vena caval CA sampling indicated that the peak levels for both NE and E were at the third lumbar vertebra. The tumor $(104 \mathrm{~g})$ was removed in April 1991. Histological analysis revealed a typical pheochromocytoma with paraganglia adjacent to the tumor. The tumor cells were immunoreacted to phenylethanolamine-N-methyltransferase (PNMT). NE and E granules appeared on electron microscopy, and the urinary NE and $\mathrm{E}$ were normalized by the surgery. These findings suggest that our case may be an Esecreting extra-adrenal pheochromocytoma.

The conversion of NE to E is catalyzed by PNMT found primarily in the adrenal medulla and the organ of Zuckerkandl. An E-secreting pheochromocytoma is generally located at either of these two sites. The classic location of the tumor to the Zuckerkandl organ is in the retroperitoneal tissue lateral to or overlying the lower portion of the abdominal aorta in the vicinity of the inferior mesenteric artery. Our case was at the typical location and had a microscopic pattern of paraganglia adjacent to the tumor. In our case, the pheochromocytoma appears to have originated in the Zuckerkandl.

Keywords: extra-adrenal pheochromocytoma, epinephrine, organ of Zuckerkandl, accessory adrenal gland, phenylethanolamine-N-methyltransferase

\section{はじめに}

褐色細胞腫は，副腎髄質あるいは大動脈周囲に存在する傍神経節を発生母地とする腫瘍で，エピネ フリン $(\mathrm{E})$, ノルェピネフリン $(\mathrm{NE})$ などのカテュールアミン $(\mathrm{CA})$ を産生, 放出する。通常, 副腎 
髄質から生じた腫瘍を副腎性褐色細胞腫, もしくは, 単に褐色細胞腫, 傍神経節からのものを paraganglioma または副腎外褐色細胞腫という。しかし，非機能性の副腎外発生例を paraganglioma と呼ぶ人もいる112)。

また，一般に NEを E に転換する酵素,すなわち phenylethanolamine-N-methyltransferase (PNMT) は主に副腎髄質に存在し, 副腎外褐色細胞腫には存在しないことが多いため, 副腎外例では NEの みが著増することが多いといわれている。しかし, 副腎外例でも $\mathrm{E}$ が高值を示す症例の報告は散見 される3) 10)。今回, 我々は, 副腎外褐色細胞腫で, $\mathrm{E}$ が異常高值を示した症例を経験したので報告 する。

症 例 : 73歳, 男性。

主 訴：口渴特よび体重減少。

現病歴：1984年に初めて高血圧を指摘され，近医にて降圧薬を投与され血圧のコントロールは良好で あった。1990年 1 月, 同医で糖尿病を指摘され, グリベンクラミド $2.5 \mathrm{mg} /$ 日が投与された。血糖の コントロールが不良であり，また，同年12月より口渴と体重減少（1ケ月で $2 \mathrm{~kg} ）$ が認められたため, 1991年 1 月に当科を紹介された。

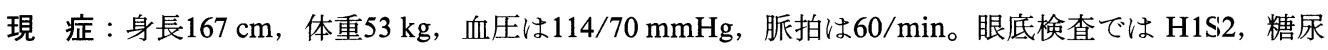
病性網膜症は認められなかった。

経過および検査成績：入院当初は血圧の変動が大きく, 頭部 CT 撮影の直後に血圧が200/120 $\mathrm{mmHg}$ と上昇したことがあったが自覚症状はなく, その後も昇圧発作は認められなかった。3月6日 の血圧日内変動でも昇圧発作は認められなかった。

Table 1 に入院時検査成績を示す。リウマチ因子が陽性, CEA が3. $8 \mathrm{ng} / \mathrm{ml}$ とやや高値を示してい

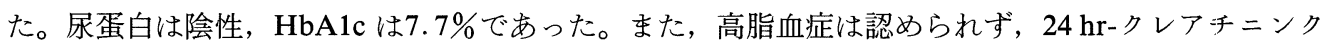
リアランスは $64.7 \mathrm{ml} / \mathrm{min}$ であった。胸部写真では心胸郭比が $44 \%$ で, 心電図では $\mathrm{T}$ 波の平低化が 認められた。

体重減少が認められ, 悪性腫瘍が疑われたため当院消化器内科で消化管等の検查が施行された。胃 透視では, 十二指腸下降部に圧排像が認められ, 腹部ェコーでは, 腹部大動脈の腹側に内部に cyst 様の構造を伴ら腫瘤が認められた。腹部 CT (Fig. 1) では腹部正中に $6 \times 5 \times 4 \mathrm{~cm}$ の腫瘤が認められ 後腹膜腫瘍が疑われた。MRI (Fig. 2) では, T2 強調像で腹部大動脈に沿って内部構造の不均一な腫 瘤が認められた。

CT スキャン, MRI など画像診断が進歩してきたため, 最近では, 褐色細胞腫には血管造影は危 険性を伴うため施行されなくなってきている。しかし，本症例では入院当初より悪性腫瘍が強く疑わ れ，また，内因性のインスリン分泌を調べる目的で施行されたグルカゴンテストで昇圧発作が認めら れなかったことから褐色細胞腫は否定的と考兄られたため, 当院放射線科で血管造影が施行された。 一過性に血圧の上昇が認められたが (最大 $190 / 120 \mathrm{mmHg}$ )，フェントラミンの点滴等により血管造影 は無事終了した。pan-aortography では下腸間膜動脈の起始部付近に vascularity と tumor stain が認 められ，また，左副腎動脈の選択的造影でも同部に tumor stain が認められた。

内分泌学的検查成績を Table 2 亿示す。血漿 NE 特よび $\mathrm{E}$ 濃度はいずれも異常高值を示し，尿中 $\mathrm{NE}, \mathrm{E}$ 抢よび vanillylmandelic acid (VMA) も高值を示した。尿中 E/CA 比は0.2であった。 
Table 1 入院時検査成績

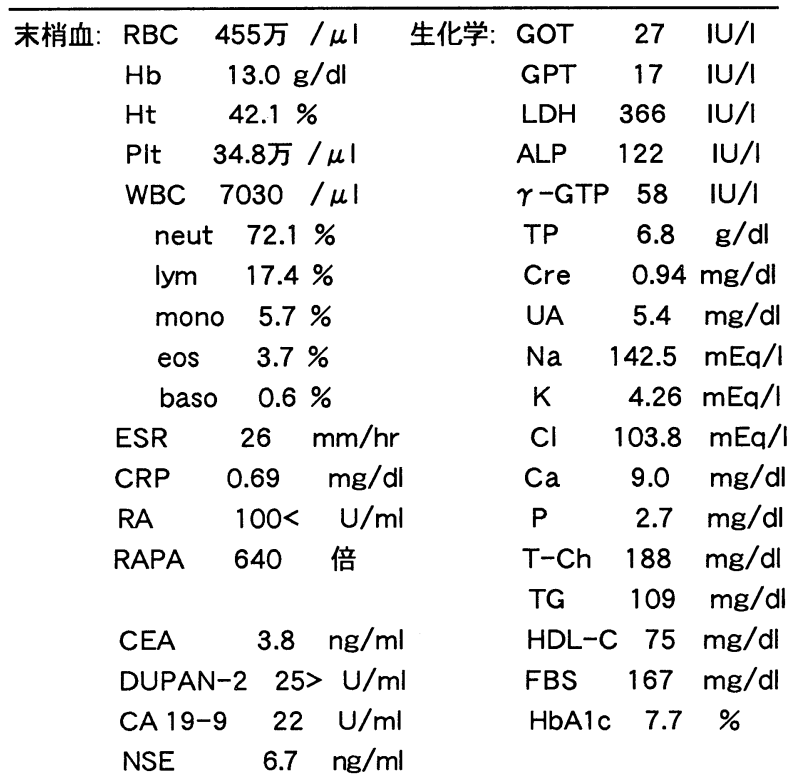

検尿 : Sugar(-) Protein(-)

Sed; n.p.

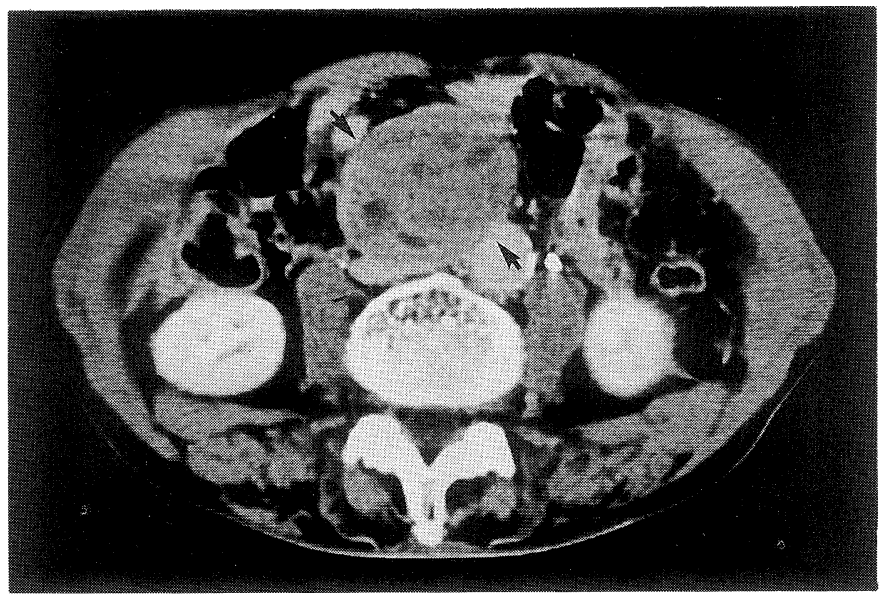

Fig. 1 CT scan of the abdomen shows an ovoid mass overling the abdominal aorta and the inferior vena cava. 


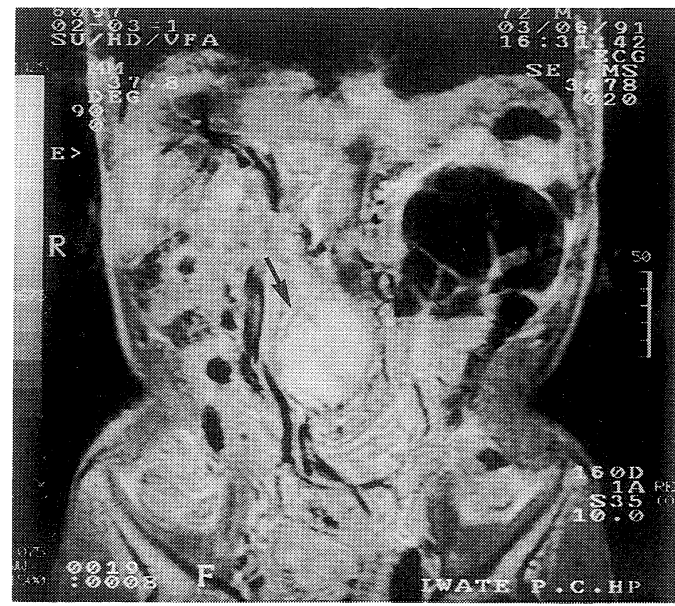

Fig. 2 T2-weighted MRI scan of the abdomen shows the heterogenous mass to the right of the abdominal aorta.

Table 2 内分泌学的検査成績

\begin{tabular}{|c|c|c|c|}
\hline 血漿レニン活性 & 1.7 & $\mathrm{ng} / \mathrm{ml} / \mathrm{hr}$ & $(0.3-2.9)$ \\
\hline 血漿アルドステロン濃度 & 67 & $\mathrm{pg} / \mathrm{ml}$ & $(35.7-240)$ \\
\hline 血漿ノルエピネフリン濃度 & 3,850 & $\mathrm{pg} / \mathrm{ml}$ & $(60-450)$ \\
\hline 血漿エピネフリン濃度 & 560 & $\mathrm{pg} / \mathrm{ml}$ & $(-120)$ \\
\hline 血漿ACTH濃度 & 42 & $\mathrm{pg} / \mathrm{ml}$ & $(30-60)$ \\
\hline 血漿コルチゾール濃度 & 12.5 & $\mu \mathrm{g} / \mathrm{ml}$ & $(4.0-18.3)$ \\
\hline 血漿カルシトニン濃度 & 41 & $\mathrm{pg} / \mathrm{ml}$ & $(-100)$ \\
\hline \multicolumn{4}{|l|}{ 尿中カテコールアミン排泄量 } \\
\hline ノルエピネフリン & $1,190-1,400$ & $\mu \mathrm{g} /$ day & $(26.0-121.0)$ \\
\hline エピネフリン & $310-350$ & $\mu \mathrm{g} /$ day & $(3.0-15.0)$ \\
\hline VMA & 26.8 & $\mathrm{mg} /$ day & $(1.3-5.1)$ \\
\hline
\end{tabular}


当時は, まだ ${ }^{131}$ I-metaiodobenzylguanidine (MIBG) シンチが施行できなかったため, 下大静脈血 のサンプリングが施行された (Fig. 3)。その結果, 第 3 腰椎の高さに NE, E ともにピークが認めら れ，CT および MRI での腫瘍の部位に一致していた。

以上より副腎外褐色細胞腫と診断され，1991年 4 月 18 日，当院外科で手術が施行された。腫場は茶 褐色で重量は104 g であった。栄養血管らしいものは 2 本あり, 選択的動脈造影で描出された左副腎 動脈の分枝ともら一本は腹部大動脈から直接流入していた。組織学的には塩基好性細胞優位型で副腎 原発の腫瘍に類似する所見であった (Fig. 4-A)。腫瘍辺縁に paraganglia が認められ (Fig. 4-B), こ の部から生じた副腎外褐色細胞腫と診断された。

電䫓像では (Fig. 5-A，5-B) NE および E 顆粒が共に認められた。また, PNMT の免疫組織染色 (Fig. 6) では, 腫瘍細胞内に PNMT が染色された。

Table 3 飞手術前後の血漿拉よび尿中 CA ならびに組織中 CA 濃度を示す。手術後, 尿中 NE, E 扣よび VMA のいずれもが正常化して拈り，また，組織内でも $\mathrm{E}$ 濃度が高值を示していた。以上の 所見はいずれも腫瘍が E が産生していた可能性を示唆する所見であった。

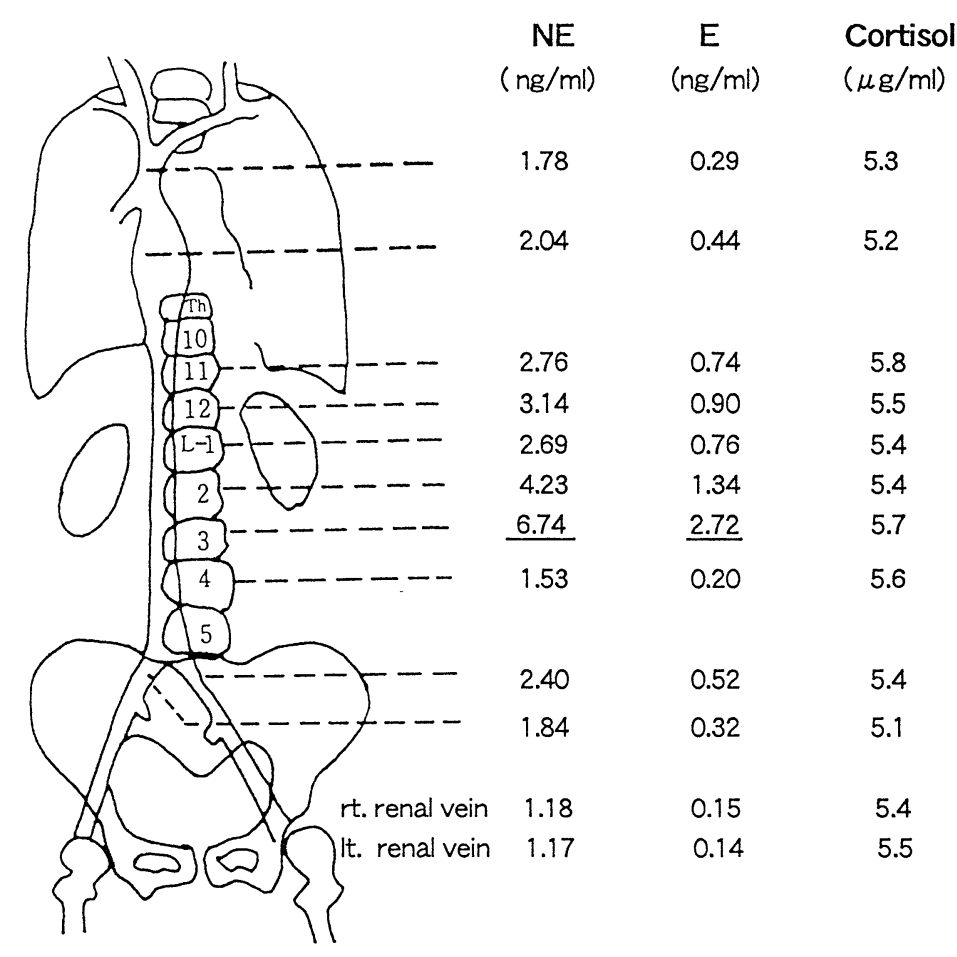

Fig. 3 Vena caval CA sampling.

第 72 巻 第 3 号 

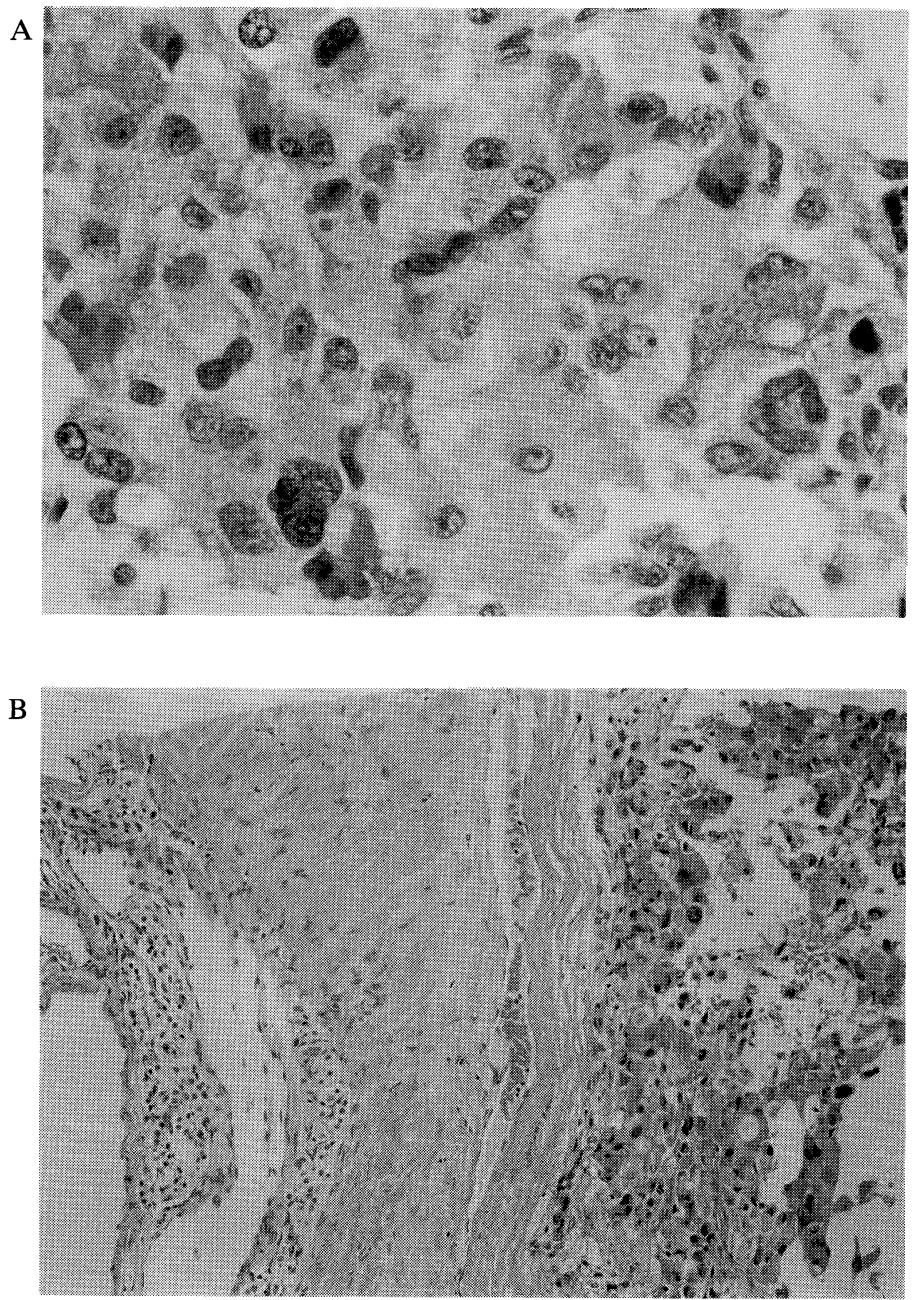

Fig. 4 A. Photomicrograph shows tumor cells that containing basophilic cytoplasma.

B. Photomicrograph shows normal paraganglion cells (left) adjacent to the pheochromocytoma (right). 

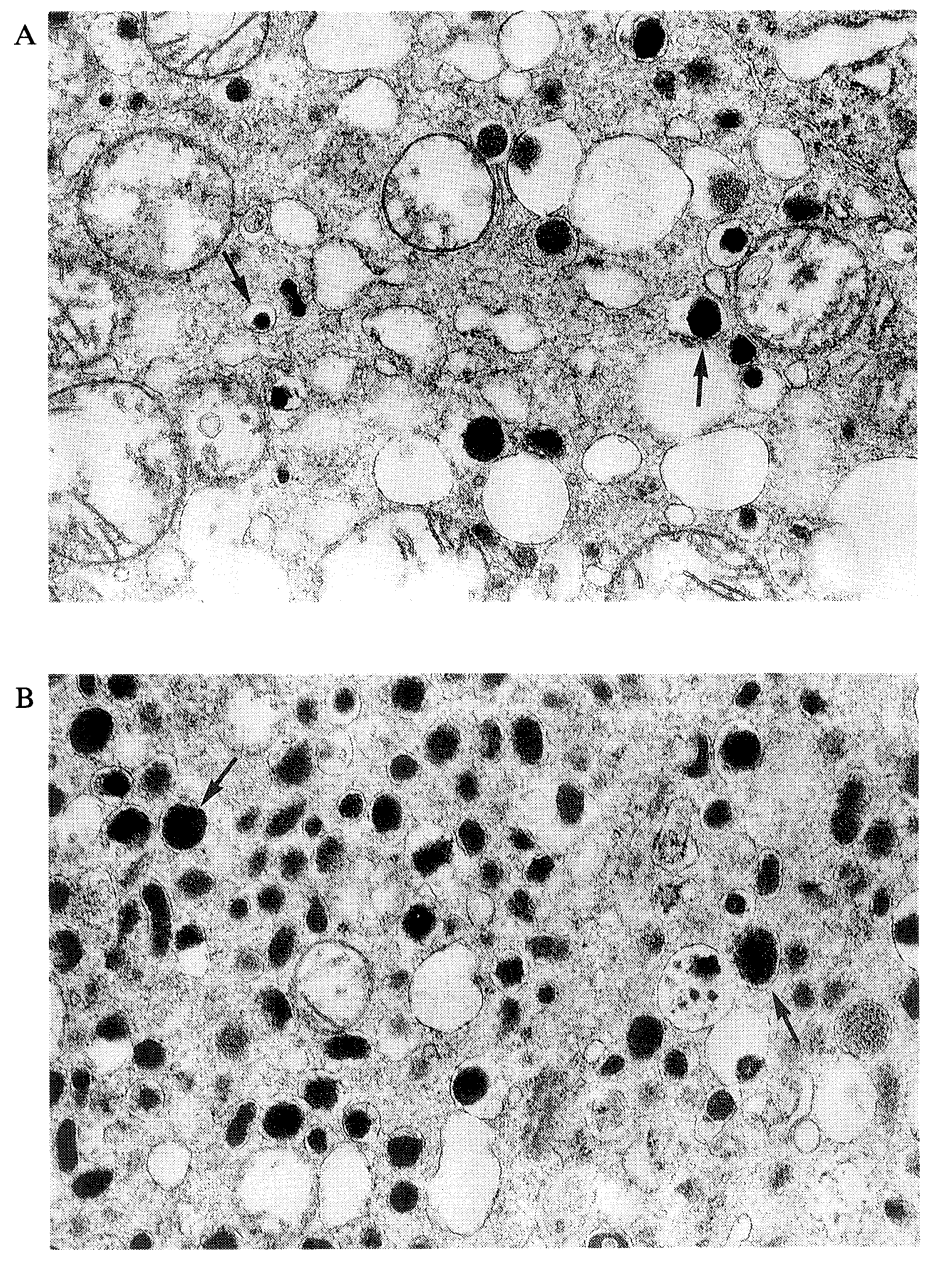

Fig. 5 Electron micrograph of a tumor cell containing many cytoplasmic CA granules (A. NE granules B. E granules). 


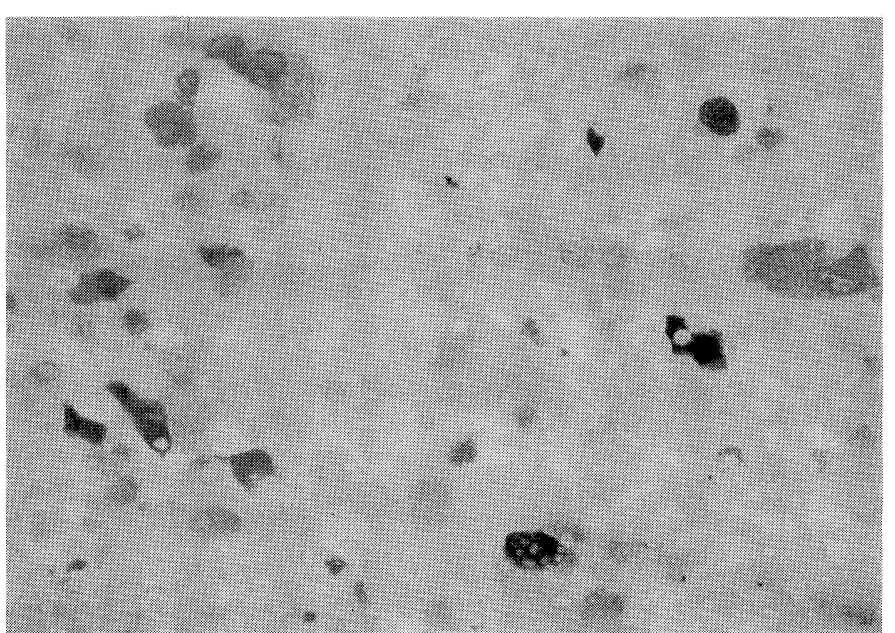

Fig. 6 Immunoreactive cells for PNMT are sporadically observed.

Table 3 手術前後でのカテュールアミンの変化と組織内カテュールアミン濃度

\begin{tabular}{|c|c|c|c|c|}
\hline & 手術前 & 手術後 & & \\
\hline 血漿ノルエピネフリン濃度 & 3.85 & 0.09 & $\mathrm{ng} / \mathrm{ml}$ & $(0.06-0.45)$ \\
\hline エピネフリン濃度 & 0.56 & $0.01>$ & $\mathrm{ng} / \mathrm{ml}$ & $-0.12)$ \\
\hline \multicolumn{5}{|l|}{ 尿中カテコールアミン排泄量 } \\
\hline ノルエピネフリン & $1,190-1,400$ & $51-88$ & $\mu \mathrm{g} /$ day & $26-121)$ \\
\hline エピネフリン & $310-350$ & $5.8-5.9$ & $\mu \mathrm{g} /$ day & $3-15)$ \\
\hline VMA & 26.8 & 3.1 & mg/day & $(1.3-5.1)$ \\
\hline 組織内ノルエピネフリン濃度 & & 8.16 & $\mathrm{mg} / \mathrm{g}$ & \\
\hline エピネフリン 濃度 & & 2.70 & $\mathrm{mg} / \mathrm{g}$ & \\
\hline
\end{tabular}

\section{考案}

副腎外褐色細胞腫では本例のごとく $\mathrm{E}$ が異常高値を示し, しか子副腎原発の腫瘍に相当する組織 型を示した症例の報告は数少ない7)。DeQuattro ら ${ }^{11)}$ は副腎性褐色細胞腫では, 通常, 全 CA. に占め

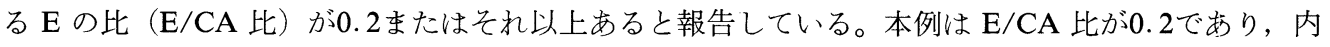
分泌学的には副腎性褐色細胞腫が疑われ, 組織学的にも副腎性と思われたが, paraganglia が腫瘍の 辺縁に存在したため副腎外褐色細胞腫と診断された。

本例は腫瘍の存在部位より Zuckerkandl 小体からの発生が疑われ, そのために, E が異常高值を 示した可能性がある。Zuckerkandl 小体には, PNMT 活性が証明されており和)13), 同部より発生し た褐色細胞腫では一部で本例のように E が異常高値を示したといら報告が認められる3゙ 6。

一方で, Zuckerkandl 小体以外上り発生した副腎外褐色細胞腫でも $\mathrm{E}$ が高值を示したといら報告 
が散見され7) 9), 発生部位に関係なく E が異常高值を示す副腎外褐色細胞腫があると考劣られる。 三浦 ${ }^{14)}$ は，褐色細胞腫は多分泌能を有し，CA 以外にも神経ペプチド抢よびステロイドホルモン 産生能を有していると総説しておう，腫瘍が PNMT 活性にその存在が不可欠といわれている2）グル ココルチコイドを産生し, PNMT の存在下で E を産生する可能性はあると考兄られる。

一方, 木村ら ${ }^{15)}$ は, 褐色細胞腫 (21例) および paragaglioma の自験例について組織学的所見と組 織内 CA 濃度との関係について検討している。つまり, 褐色細胞腫を組織学的に 1. 明細胞優位群, 2. 塩基好性細胞優位群, 3. oncocyte 優位群の 3 型に分類し, 1. と 3. は腫腸中に NE の含有量が 多く（E/NE 比は 0-0.12），2.は E が多かった（E/NE 比は0.58-6.01）と報告している。また， paraganglioma 飞ついては，Zuckerkandl 小体由来の 1 例を含む 6 例について検討し， 5 例が明細胞 優位型で, 1 例が oncocyte 優位型であり, 塩基好性細胞優位型を示した症例はなかったとしている。 本症例は, 腫瘍中の $\mathrm{E} / \mathrm{NE}$ 比が0.33 と比較的高く, また, 塩基好性細胞優位型を示した paraganglioma であり, 同様の症例は彼らのその後の報告16)にもなく, 比較的稀と考兄られた。

また，本症例では，左副腎動脈の分枝が腫瘍の栄責血管の 1 つと考えられた。一般に，Zuckerkandl 小体の栄養血管は腹部大動脈から直接流入すると報告2)されて扣り, 本腫瘍の栄養血管が副腎 動脈の分枝であったことは本腫瘍が副腎組織と何らかの関係のあることを示唆すると考学られる。副 副腎は Morgagni により初めて報告されているが，本邦では，1987年に小山田ら ${ }^{17)}$ が84例（104個） そついて集計し, その存在部位は, 本来の副腎付近, 腎周囲, 広勒帯, 卵巣周囲, 膀脱周囲, 精索, 睪丸, 副睪丸付近と報告している。一方, 胎児から新生児での剖検所見では0.7-9.1\%に副副腎が認 められたと報告1819) されているが，本来の機能的な副腎の存在下では生理的に不要となり漸次萎縮 し, 思春期前に消失してしまらといわれている。しかし, クッシング症候群, アルドステロン症, 副 腎性器症候群, 褐色細胞腫など機能性の副副腎腫瘍の報告20) 22) も認められ, また, 副副腎の栄養血 管が副腎動脈であった症例も報告 ${ }^{23)}$ されている。本症例では左副腎動脈の分枝が腫瘍の栄養血管の

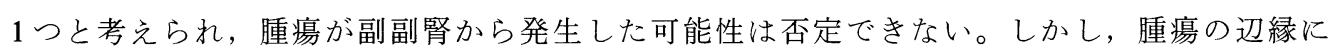
paraganglia が認められたことは，本腫瘍の発生母地が副副腎であると考劣るより， paraganglia，つ まりZuckerkandl 小体が腫瘍化したと考光た方が良いと思われた。

以上, $\mathrm{E}$ が異常高值を示した副腎外褐色細胞腫の一例を報告した。従来, 副腎外褐色細胞腫では, NE のみが著増することが多いといわれ，その説明として副腎髄質以外では PNMT 活性が低いため

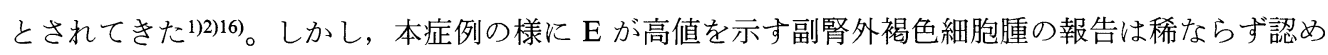
られ，発生部位とCA の関係は必ずしも一致しないと考它れる。

本症例は，その存在部位より Zuckerkandl 小体より発生したと考兄られたが，腫瘍の栄養血管が 副腎動脈の分枝であったことは大変興味深く, 副腎外褐色細胞腫の発生部位を考えるら壳で副副腎も 念頭にいれて検討する必要があると思われた。

また，今回腫瘍中に PNMT 活性を証明することができたが，この様な CA 生合成に関与する種々 の酵素抗体による免疫学的検討は副腎外褐色細胞腫での $\mathrm{E}$ の産生や非機能性副腎髄質腫瘍の CA 分 泌に関しての検討に役立つと考えられている24)。しかし, 電顕像や免疫組織学所見等, 病理学的に十 分に検討された報告は数少なく7244), 症例を重ねて検討する必要があると思われた。 
謝辞

稿を終えるにあたり，電顕像，PNMT 免疫組織染色など貴重なご助言を賜りました東北大学第 2 病理木村伯子先生に深謝致します。

\section{文献}

1) 佐藤辰男 : 副腎外褐色細胞腫（パラガングリオーマ)。 日本臨床. 1993；51(増刊号＼cjkstart本邦臨床統計集)，526-529

2) Whalen, R.K., Althausen, A.F., Daniels, G.H.: Extra-adrenal pheochromocytoma: J. Urol. 1992; 147: 1--10

3) Altergott, R., Barbato, A., Lawrence, A., Paloyan, E., Freeark, R. J., Prinz, R. A.: Spectrum of catecholaminesecreting tumors of the organ of Zuckerkandl: Surgery. 1985; 98: 1121-1125

4) Ciobotaru, M. , Eisenman, A., Veisler, A., Freud, M. : Pheochromocytoma of the organ of Zuckerkandl presenting as shock: Isr. J. Med. Sci. 1985; 21: 517-519

5) Nishiyama, T., Ono, M., Nohe, T., Seo, Y., Hara, Y., Abe, M., Hayashi, I.: Functioning paraganglioma in the organ or Zuckerkandl associated with esophagus carcinoma: A case report: J. Surg. Oncol. 1982; 20: 182-186

6) Crout, J. R., Sjoerdsma, A.: Catecholamines in the localization of pheochromocytoma: Circulation. 1960; 22: 516-525

7) 石川 晃, 中野 優, 安田 滋, 中村孝哉, 大田原佳久, 田島 惇: 無症候性副腎外褐色細胞腫の 1 例. 泌外. 1991; 4: $317-319$

8) Engelman, K., Hammond, W. G. : Adrenaline production by an intrathoracic pheochromocytoma: Lancet. 1968; i(1): 609-611

9) Mannix, H. Jr., O’Grady, W.P., Gitlow, S. I. : Extra-adrenal pheochromocytoma-producing epinephrine: Arch. Surg. 1972; 104: 216-217

10) 阿部圭志 : 二次性高血圧症の診断と治療一最近の進歩一. 日内会誌. 1994; 83: 200-207

11) DeQuattro, V., Myers, M., Campese, V. M. : Pheochromocytoma: Diagnosis and therapy: In: Degroot L. J., ed. Endocrinology. Philadelphia: W. B. Saunders Company, Harcout Brace Jovanovich Inc., 1989: 1780-1797

12) Schenker, J. G., Chowers, I. : Pheochromocytoma and pregnancy, Review of 89 cases: Obstet. Gynecol. Surv. 1971; 26: 739-747

13) Axelrod, J.: Purification and properties of phenylethanolamine-N-methyl-transferase: J. Biol. Chem. 1962; 237: $1657-1660$

14) 三浦幸雄 : 副腎髄質, III 内分泌，B ホルモン各論. Ann. Rev. 内分泌，代謝 1991; 232-240

15) 木村伯子, 中村克宏, 若狭治毅, 笹野伸昭, 小林 清, 三浦幸雄, 渡辺 至 : 神経芽腫群腫瘍, 褐色細胞腫及びパラ ガングリオーマの超微形態一腫瘍内カテュールアミン含量との相関. 最新医. 1981; 36: 159-167

16) 木村伯子, 笹野伸昭: 副腎髄質, 傍神経節; 肥大, 過形成, 腫瘍. 現代病理学大系 17B, 内分泌系 II, 中山書店, 1991; 237-304

17) 小山田ゆみ子, 小山田正人, 吉田 豊, 小川勝洋, 小谷俊一 : 病理と臨. 1987; 5: 1361-1364

18) 立川 保：腫瘍発生飞関卞る胎生病理学的研究補遺. 長崎医会誌. 1963; 38: 98-108

19) Sasano, N. : Noninflammatory calcification in the human adrenal glands proper and accesory, and in adrenocortical adenoma: Tohoku J. Exp. Med. 1964; 83: 342-352

20) 石井泰憲, 富永登志, 横山正夫, 高見茂人, 毛利 昇, 阿曽佳郎 : 補副腎皮質腺腫による Cushing 症候群の 1 例. 臨 泌. 1978; 32: 773-777

21）村橋 勲, 高橋悦司, 浅野美智雄, 岸 洋一: Adrenal rest の Adenoma による Primary Aldosteronism について. 臨 泌. 1972; 26: 43-47

22) 内藤敬子, 山田健二, 井上一博, 板津武晴, 小林正明, 安藤 正, 木幡浩司 : 右腎門部の微小副副腎髄質過形成によ る褐色細胞腫の 1 例. ホルモンと臨床. 1987; 35: 67-71

23) 橋本邦宏, 森山浩之, 福重 満, 福原敏行, 川野洋治, 岩永壮二, 木村昭二郎, 伊藤和朗 : 副副腎より発生したと考 えられる内分泌非活性副腎皮質腺腫の 1 例. 泌外. 1992; 5: 701-704

24) Kimura, N., Miura, Y., Nagatsu, I., Nagura, H. : Catecholamine synthesizing enzymes in 70 cases of functioning and non-functioning pheochromocytoma and extra-adrenal paraganglioma: Virchows. Arch. [A] 1992; 421: 25-32 